\title{
Construction of the Language and the Structure of News Text in Blog
}

\author{
Riskha Arfiyanti, Indonesia University of Education \\ Syihabuddin, Indonesia University of Education \\ Vismaia S. Damaianti, Indonesia University of Education \\ Dadang Anshori, Indonesia University of Education
}

\begin{abstract}
Information dominates people's lives and becomes the main every day consumption in the digital age.This is supported by the easy and the speedyaccess of information that can be obtained from various sources, especially through online media. Production and dissemination of information belong to anyone. The emergence of the internet, more specifically the presence of various social media, such as blogs allows anyone to do this activity.Blogs become one form of effective media to spread news. The abundance of information also raises varieties of issues, such as the information accuracy, the objectivity, and the hoax news. Therefore, it requires bloggers abilities to write good news. This article aims to describe the abilities of bloggers in writing news text that is studied based on the characteristics of the constructionofthe language structure.Language structure construction is a good journalistic writing standard. The research method used is ananalyticaldescriptive approach. The source of research data is a trending topic news text written on the blog sitesof the Cirebon's blogger community. The results of the analysis show the overall ability of bloggersin news writing observed from the structure and the language aspect that the structure is identified to be good enough, yet the language use has not been entirely met the requirements of good language of news.
\end{abstract}

Keywords: blog; language of news text; news text; news text structure; online media; the ability of bloggers to write news

\section{Introduction}

The presence of online media as an impact of the information technology developmenthas led to the information revolution. Information dominates people's lives and becomes the main everydayconsumption. Fuchs and Sandoval (2014) stated that information is one of the several dimensions that relevant to today's society.Production and dissemination of information as a form of journalistic activity now belongs to anyone. The emergence of internet, more specifically the presence of various social media such as blogs allows anyone to do activities, including blogging. People can find variousinformations in blog, including news. Research conducted Chai and Kim (2010) found that there is a positive relationship between the trust of bloggers and the information sharing activities. The results of the Savolainen (2011) study also proved the same thing that blog can be an emotionally supportive forum for the purpose of sharing information and opinions. Popular issues in the blog could attract attention and give a big influence to the community (Hsu \& Lin, 2008).

Blog become one form of effective media to spread news. Alternative news sources on the Internet, such as blogs, web portals, and social networking sites are good competitors for mainstream media (Noor, 2017). Based on the results of his study, Noor concluded that citizen journalism has become potential source of news, especially news that cannot be accessed by professional journalists. Robinson and De Shano (2011) highlighted the similarity of the role of professional bloggers and journalists which are bordered by the values of social responsibility, the information access, the right to knowledge, and the professionalism.

The abundance of information also raises a variety of issues, such as the accuracy of information, the objectivity, and the number of hoaxes. Users' trustsfor online news site is influenced by the contents of the information. The results of Go, Yu, Jung, and Shim (2016) study showed that the use of online news sources greatly affects users' perceptions of the online information credibility, as well as the press confidence. The findings of Jung, Childers, and Kim 
(2016) research on the diet and nutrition information from a website showed that the credibility of a site is determined by the information accuracy that is influenced by the author expertise. Thus, the ability of bloggers in writing good news impacts the content information of the news sites.

News has its own characteristics that distinguish it from other journalistic writings, including the content, the style, the structure, and the language use. Blogers have to master those characteristics in order to write a good journalistic writings that allow readers to understand the information conveyed.This study focuses on the ability of bloggers in writing news observed from the structure and the language aspects. The role ofimportant news structures and languages in determining the journalistic standardization had been understudied (Cotter, 2010). Furthermore, Wariya (2016) pointed out the importance of language characteristics to express ideas, attitudes, and to convince others.

Reviews of the structure and the languageof news text have been done by previous researchers. However, inspecting bloggers ability to write news by investigating the structure of the newshas rarely been done. Research examining the structure and the development of newspaper headlines had been done (Khak, 2014). Several other studies have also been focused on the meaning of the news text (Hermina, 2014 \& Queen, 2016). Both studies examined the meaning of news text through critical discourse analysis of Van Dijk. The use of news text had been reviewed by Arsita, Rusminto, and Fuad (2014). They studied the use of affixes found in the headlines of Lampung Post newspaper. Researchon journalistic language had also been conducted by Catenaccio et al. (2011), Dewi (2014), Han (2011) and Hardi (2015). Catenaccio, et al (2011) studied the role of linguistic analysis in the news language. In addition, Dewi (2014) examined the style of language in online news headlines in Indonesia. Meanwhile, Han (2011) analyzed the use of metaphors in online entertainment news in China. To dd more, Hardi (2015) reviewed the level of propriety of journalistic language on the online media site.

\section{Literature review 2.1 Blog}

A blog is one of the popular social media platforms since blog providesa free space to everyone to express opinion and share information compared to any other social media platforms. In addition, blog also allows readers to respond directly to the posts that make bloggers to be able get useful feedback for their writing. Blog is a website that contains a series of chronological posts (Poynter, 2010). At the beginning of the $21^{\text {st }}$ century, blog focuses more on comments, links and, reader responses that depend on the theme and the purpose of the weblog (Pedersen, 2010).Blog encourages citizen journalism. Everyone can share information about themselves and the circumstances around them. Blog gives everyone the opportunity to participate in the public sphere (Seib in el-Nawawy \& Khamis, 2013). Now, blogs are news. Bloger is a reporter and an editor for politics, business, science, and entertainment coverage (Walsh, 2007). Thus, it can also be said that blog is a news source just like other mass media.

\subsection{News text}

News as one of the journalistic products is the most important information that can be obtained in mass media. News is defined as something new that has just happened or is about to happen and something that is immediate, exciting, unusual, unexpected, amazing, vital, and interesting (Pape\& Featherstone, 2005). As information technology advances, news is presented in various media formats, whether printed, electronic, or online, including blogs. In fact, at this moment,the production, the dissemination, and the consumption of online news media are rapidly increasingcompared to other mass media. Online media has certain characteristics. Thus, they certainly affect the writing of news in online media. Karlsson (2011) mentioned two important features of online news, namely user participation and immediacy. Online news editors reveal that online news writing is similar to the writing of printed news. The online news is very sharp, concise, and personal (Thompson, 2010). Thus, online news writers including bloggers need to master the ability to write good journalistic writings in online media. 


\subsection{Structure and language of news text}

The ability of bloggers in writing news can be seenfrom several aspects, suh as from the structure and the language use.The most commonly used structures of news arethe inverted pyramid (Hercules, Adams, Gilbert, \& Holmes, 2008), the hourglass and the narrative storytelling (Foam, 2014).This study uses inverted pyramid structure. The inverted pyramidsructure is usually used for hard news. This structure can be used as a formula for analyzing, training, and teaching news writing (Hicks, Adams, Gilbert, \& Holmes, 2008). The news structure in newspapers, as well as in online news, is often structured in the form of the inverted pyramid. This structure is structured according to the notion of importance. This means that the most important story element is placed on the top (lead) followed by the detailed informationthat is placed in the next section (body).

With all of its limitations, Foam (2014) reinforced that the inverted pyramid structure is considered as the favorite structure in composing news. The inverted pyramid is the best format to deliver effective, clear, and fast news. This structure is appropriately used in the online news since the users like skimming the news. This structure gives advantage to the readers that in order to easethem in finding important elements, they only need to look at the beginning of the story without having to read the whole.

Like the news structure, the journalistic language also has certain standards. The standards include important formulas for writing news, the principles of "kiss and tell", keep it short and simple and tell the story (Foam, 2014; Pape\& Featherstone, 2006; and Reeves \&Keeble, 2015). Those principles are essential in creating good journalistic writings. In accordance with the principles, news is written in simple and concise language, in short paragraphs, in active rather than passive sentences, and in avoidance ofcliches. Reeves and Keeble (2015) suggested that complex sentences with long subordinate clauses need to be avoided. Furthermore, McKane (2006) suggested that the use of news language should pay attention to the word selection, sentence structure, grammar, spelling, and punctuation. The language principle of news text is used as an analytical tool to determine the bloggers ability in writing news.

\section{Research method}

This research uses analytical descriptive method. The source of the research data are news posted in Cirebon blogger community website that available at www.bloggercirebons.co.id during May 2017. It is due to the fact that compared to other months, most news is found to be posted in the website during that month. Cirebon bloggers community was chosen because of its role in disseminating information. Data collection techniques include primary and secondary data. The primary data used in this study is news posted on the blog, while the secondary data is literature studiesthat can be in the form of both books and journal articles related to the research variables. The current research studies the content of the news, specifically the structure and the language aspects.

\section{Results and discussion}

\subsection{Construction of news text structure}

Based on the observations, in May there are17 news. News texts analyzed are the trending topic newstexts that cover news about the incident of accident, disaster, visiting family, and economy. There are four components composing news text, namely headline, byline, intro/lead, and body that each of them is observed to have different purpose (Foam, 2014). The discussion focuses on the titles and the leads that contain important information. The structure of headlines can be in the form of phrase, sentence, or clause. Based on the results of the analysis, four news has a structure of compound sentence, which appear in the following titles: (1) Menjelang Puasa, Harga Bawang PutihNaik 77 \% di Pasar Jagasatru, (2) Mobil Truk Nabrak Warung di Cirebon, Dua Orang Meninggal di Tempat, (3) Jelang Mudik 2017, Pintu Tol Tegal Karang Palimanan Kembali Dibuka, and (4) Puluhan Rumah Warga di Empat Desa Rusak Berat Tersapu Angin Putting Beliung. 
The four titles are in the form of compound or complex sentences because the structure consists of two single sentences. This compound sentence is composed by a major clause and a subordinate clause.

Inverted pyramid structures are arranged in importance orderthat place important information at the beginning of the paragraph. Therefore, generally the news emphasizes the leads. McKane (2006) identified the characteristics of leads used as the analytical tool in this paper that compriseie the number of words, the main ideas, the $5 \mathrm{~W} 1 \mathrm{H}$ components, the use of active sentences, and the avoidance of direct quotation.

McKane (2006) mentioned the number of words for effective leads are around 20-25 words or less than 30 words, but it must be able to draw attention and inform the most important thing. In accordance with the characteristics of the Indonesian language, Sumadiria (2014) noted that it should be around 30 and 45 words. For example, the news text leads (4), "Puluhan rumah warga terkena imbas angin putting beliung yang menyapu rumah warga di empat desa,...." consisted of 28 words. This lead contains important information that summarizes news content and is relevant to the title.Lead also draws attention to the use of a more valuable word imbas than the word akibat.

The leads should consist of 1-3 main ideas. Leads that contain many ideas will make readers difficult to understand the content or to capture the important elements of the story. Slickly, the blogger community composes 1-2 lead ideas for the four samples of news analysis. For example, lead (4) only contains one idea that is the number of houses affected by the tornado.

Lead generally contains components that answer $5 \mathrm{~W} 1 \mathrm{H}$ questions i.e. what, who, when, where, why, and how. According to Rudyard Kipling as quoted in Hicks, Adams, Gilbert, and Holmes (2008), the components are useful to test the news. Although they are not fully contained in the leads, it is a good idea to check whether or not in the lead there found the components. All of the components will be answered on the whole news content. Leads do not always started with time or place. The elements that are important must be presented in the leads (McKane, 2006, Hicks, Adams, Gillbert, \& Holmes, 2008). Among the four news, there are two news that begun with the element when, which can be seen in the news text discussing about about the accident.This is apparent in the following sentence"Sekitarpukul 21:00 WIB sebuah mobil truk tiba-tiba menabrak warung...."

The sentences in the lead and in the next section should use active sentence construction. Active sentences are more powerful than passive sentences. Active verbs are also easier for readers to understand. Meanwhile, passive sentences complicate understanding. Thus, the sentence "Mobil menabrakwarung." has stronger meaning than "Warung dita brak mobil." However, based on the analysis, there are several sentences in leads that do not use active verbs, such as"Gerbang tol kembali dibuka."

McKane (2006) suggested that effective leads are not started with direct quotes. Leads with direct quotes are mostly needed in events that contain elements of conflict. This lead is chosen with the consideration that the words are of crucial, clear and concise. Quotes in leads are usually used in softnews. All of the four news leadsleave direct quotes. The following are the lead descriptions for news texts on accidents, disasters, visiting family, and economics.

News Text 1:

Menjelang bulan puasa yang tinggal menghitung hari, harga sembako mulai merangkak naik. Tercatat di Pasar Jagasatru, Kota Cirebon, untuk harga bawang putih jenis kating atau jenis lanang mengalami kenaikan hingga $77 \%$.

The lead consists of 31 words. The main idea is about the increasing price of basic foods, specifically onions. This leadis considered to be categorized in the type of time news leads because it has theelements of time, what (harga sembako), and where (Pasar Jagas atru). The sentences contain active verbs and are not started with a direct quote. 


\section{News Text 2:}

Sekitar pukul 21:00 WIB sebuah mobil truk tiba-tiba menabrak warung pinggir jalan, persisdepan SPBU BunderanKedawung, Kabupaten Cirebon. Mobil truk yang menabrak warung itu menewaskan Sri Sugianti (52) istri dari Agus Taufan (48).

The lead consistsof 32 words and starts with time followed by other elements, such as who (truck car), what (crashed), and where (in front of the pump). This lead contains two main ideas. The lead summarizes the essential core of the news which is relevant to the title. In addition, the lead prioritize active sentences.

News Text 3:

Ada kabar bagus untuk pemudik di tahun 2017 ini. Khususnya pengguna jalan tol Tegal Karang, Palimanan, Cirebon. Karena saat ini gerbang tol 1,2 dan 4 Palimanan sudah dibuka, Selasa (2/5/2017) kemarin.

The lead consistsof 31 words, emphasizing what element. The lead contains 1 idea, but less neat because it contains ineffective sentences and passive sentences. The lead contains core information that is relevant to the title, and does not start with direct quotes.

News Text 4:

Puluhan rumah warga terkena imbas angin putting beliung yang menyapu rumah warga di empat desa, yakni desa Mertasinga paling terparah kemudian desa Purwawinangun, desa Muara, dan desa Sirnabaya.

The lead consisting of 28 words, gives priority to what element. The lead contains one idea and contains important information that summarizes the news content. This lead also attracts attentionthat can be observed from the diction, for example the word imbasthat is considered to have more value than the word akibat.

The inverted pyramid structure is described in the following section using an example taken from one of the texts. The news text (4) consists of five paragraphs. This text informs the natural events of the tornado in one district inCirebon. As the result of this incident, many houses are damaged. Overall, the news story is reflected in the headline. The headline is then expanded on the first paragraph of the lead of the news. The lead contains topic sentences from the whole story, which is about the number of houses and villages damaged by the tornado. Paragraph two provides the detail information of the lead, i.e. the time of the event and the process of the occurrence. The third paragraph adds to the facts of the lead. In this paragraph, the locationthatworstly damaged, Mertasinga Village is specifically mentioned in the lead. The fourth paragraphinforms the details of the total damaged houses in the four villages. The final paragraph becomes the closing story that provides additional information about the estimated loss, the government assistance, and the casualties of this event. However, the disclosed information is very slightso that it does not reinforce the message of the story and does not affect the overall story in general.

\subsection{Construction of news text language}

The language of the news text is analyzed based on thediction and the spelling. The news paragraph should be short. It means that the paragraph is composed by a simple, short, and clear sentence structure. In the four news texts, most of the sentences written by the blogger community are simple and short sentences. The following sentences will be easier to understand. Take for instance, the text of the news (2), the phrase "Hingga saat ini jasad korban dibawa ke Rumah Sakit Gunung Jati untuk dilakukan pemeriksaan lebih lanjut"is constructed of single sentence patterned on Adverb-Subject-Predicate-Adverb (K-S-P-K). The sentence is composed of short words and phrases. The sentence in the text (2), as well as in the other three news texts, is also largely composed by a single sentence. Although there are several compound sentences, the sentence is at least constructed by one main clause and one subordinate clause.

In the posted news texts, ineffective sentences are still found, either in the form of the inaccurate use of conjunctions, the wastage of word, or the non-logical meaning of the sentence. In fact, effective sentence are very decisive in affecting the decision whether the content of the 
news is understandable or not.The ineffective sentences due to the inaccurate use of conjunctions appear in the news texts (3) and (4). For example, in the sentence "Sehinggamasyarakatterkenadampaky." the word sehingga is a conjunction that should not be put at the beginning of a sentence.Thus, as the result, the sentence becomes ineffective since a clause cannot stand alone. Meanwhile, the wastage of word appears in the four news texts, for example in the sentence in the third paragraph. In the news text (3), "Terutama di jalur bypass Kelangenan yang menjadilebihseringterjadikemacetan...." the word menjadiand terjadimake the sentence becomes ineffective. The omission of words menjadi can create the more effectivesentence. In addition to those two things, logic is one of the requirements for preparing a good sentence. However, there is still an illogical sentence that can be discovered in the news text (1), "AgusTaufanmenderitaluka-lukasaatmenunaikansalatisya. "Bloggers do not give an explanation of whoAgusTaufanis that make the reader confused. Then, in the sentence it is observed that there is no connection between injury and prayer.

Word selection should be considered in writing news. Appropriate and compelling words can stimulate their readers. The blogger community can choose a word that can convey the meaning correctly, for example bloggers prefer to use the word nahas which is more specific in conveying the event than the word sial or celaka. Similarly, the word menyapu in the sentence "...angin putting beliung sangat kencang menyapu genteng rumah..." is more meaningful and memorable that make the story more alive. Bloggers also use words that are popular or common sothat the information is easily understood.In the news text a variety of spoken language exists, it can be seen from the occurrence of the word nampak that should be tampak.

In addition, another thing that must be considered in writing news is the spelling. Spelling analysis is done following the rules of the Indonesian Spelling Guideline (PUEBI) which includes the use of letters, the word writings, and the use of punctuation.The blogger community has not fully implemented the spelling rules in writing the news text. It is observed from the existence of errors in the use of letters, such as the use of capital letters, the use of nonstandard word writing, and the use of comma and other punctuations. Incorrect capital letters are found in the news text (2) and (4), such as desa Mertasingaand Kg.The word followed by the name of geography should begin with capital letters so it must be writtenDesaMertasingaand $\mathrm{Kg}$ should be writtenkg.The wrong word writing appears on the word tak sempat that should have been written tak sempat, the word naas should be nahas, and the word menyebrang should be menyeberang. The use of less precise punctuation is illustrated in the news text (2), (3), and (4), for example, the sentence in the news text (3) "Ada tigagerbangtol yang dibuka. Yakni Gerbang Tol Palimanan 1, 2, dan 4." The placement of the dot in the sentence is less precise because the next part is the detail for the previous word. The proper punctuation should be a comma. In addition, the use of improper punctuation can change the meaning of the information.

Based on the results of the analysis, the blogger community does not apply the journalistic standards. Additionally, the mastery of journalistic language still needs to be improved. The evidence can be traced in the four news texts that contain errors in all aspects of language, which are sentences, words, and spelling. The results of this analysis are related with what Milroy and Milroy found (in Cotter, 2010) regarding the complaints of infringements of the correct language use in both public and professional journalism organizations of news text.Milroy and Milroy (in Cotter, 2010) statedthat there are legalistic complaints related to grammatical errors, punctuation, pronunciation. Thus, Thompson (2010) asserted that internet journalists have to master the rules of writing news text, such as spelling, punctuation, and formatting, to get accurate and consistent text.

\section{Conclusion}

Several previous studies have shown that blogs are social media platforms that can be used to spread information, such as news. News has structure and construction of language that can be called as the standard journalistic writing. The construction of news text in the blogger 
community blogs follows the inverted pyramid structure. Although it might be considered traditional, this structure is quite effective in presenting information because the reader can capture important information easily and quickly only by looking at the beginning of the story. Meanwhile, journalistic language standards include sentence structure, word selection, and spelling. Overall, the use of the news text language has not applied grammar and spelling rules appropriately. The mastery and the understanding of the structure and the language of news texts become very important for bloggers in order to convey the appropriate information and to ease the readers in comprehending the news. The credibility of the authors (bloggers) will appear on both constructions. Thus, the reader can make the blog as an alternative source of information that is as credible and reliable as other mass media. In addition, blogs can also enrich the Indonesia's mass media information since they can meet the societies' need of information.

\section{References}

Arsita, T.Y., Rusminto, N.E., \&Fuad, M. 2014. Afiks dalam berita utama surat kabar Lampung Post. Jurnal Kata (Bahasa, Sastra, dan Pembelajarannya), 1-13.

Busa, G. M. 2014. Introducing the language of the news: A students guide. London and New York: Routledge.

Catenaccio, P., et al. 2011. Towards a linguistics of news production. Journal of Pragmatics, 43, 1843-1852.

Chai, S. \& Kim, M. 2010. What makes bloggers share knowledge? An investigation on the role of trust. International Journal of Information Management, 30, 408-415.

Cotter, C. 2010.News talk: Investigating the language of journalism. New York: Cambridge University Press.

Dewi, M. 2014. Gaya bahasaberita media online di Indonesia: Judul menariktidak harus tidak baku. Humaniora, 5(2), 1015-1022.

El-Nawawy, M \&Khamis, S. 2013. Egyptian revolution 2.0: Political blogging, civic engagement, and citizen journalism.New York: Palgrave Macmillan.

Fuchs, C. \& Sandoval, M. 2014.Introduction: Critique, social media and the information society in the age of capitalist crisis. In Fuchs, C. dan Sandoval, M (ed.). Critique, Social Media and the Information Society. New York: Routledge.

Go, E., Yu, K.H., Jung, E., \& Shim, H. 2016. Why do we use different types of websites and assign them differentlevels of credibility? Structural relations among users' motives, typesof websites, information credibility, and trust in the press. Computers in Human Behavior, 54, 231-239.

Hardi, N.M. 2015. Tingkat kepatutanberbahasajurnalistikpadajurnalisme online di situs detik bandung.com (Studi deskriptif dengan teknik analisis isi terhadap penerapan kaidah bahasa jurnalistik berita langsung (straight news) di detikBandung.com). Komunikatif Jurnal Ilmiah Komunikasi, 4(2), 33-43.

Hennessy, B. 2006. Writing feature articles. Oxford: Focal Press.

Hermina. 2014. Analisis wacana berita kisah-kisah dari perbatasan Negara (Liputan khusus edisi Minggu 12 Juni 2011 KaltimPost). E Journal Ilmu Komunikasi, 2 (3), 229-243.

Hicks, W., Adams, S., Gilbert, H., dan Holmes, T. 2008. Writing for journalists. Second edition. London dan New York: Routledge.

Hsu, C.L. \& Lin, J. C.C. 2008. Acceptance of blog usage: The roles of technology acceptance, social influence and knowledge sharing motivation. Information and Management, 45, 65-74.

Jung, E. H., Childers, K. W., \&Kim, H. S. 2016.Factors influencing the perceived credibility of diet-nutritioninformation web sites. Computers in Human Behavior, 58, 37-47.

Karlsson, M. 2011. The immediacy of onlinenews, the visibility of journalistic processes and a restructuring of journalistic authority. Journalism, 12 (3), 279-295.

Khak, A.M. 2014. Structure and development of hard newsof Indonesian language mass media. Metalingua, 12(1), 97-113. 
McKane, A. 2006. News writing. London, California, \&New Delhi: Sage Publications.

Noor, R. 2017. Citizen journalism vs. mainstream journalism: A study on challenges posed by amateurs. Athens Journal of Mass Media and Communications, 3(1), 55-76.

Pape, S. \& Featherstone, S. 2005. Newspaper journalism: A practical introduction. London, California, \& New Delhi: Sage Publication.

Pape, S. \& Feather stone, S. 2006. Feature writing: A practical introduction. London, California, New Delhi: Sage Publication.

Pedersen, S. 2010. Why blog? Motivations for blogging.Oxford: Chandos Publishing.

Pedoman Umum EjaanBahasa Indonesia. Available at badanbahasa.kemdikbud.go.id. (Accessed19 June 2016).

Poynter, R. 2010. The handbook of online and social media research: Tools and techniques for market researchers. United Kingdom: John Wiley \& Sons Ltd.

Queen, D. S. 2016. Analisis wacana berita konflik KPK VSPolri di Kaltim Post (Edisi bulan Januari 2015). eJournal Ilmu Komunikasi, 4 (3), 112-126.

Reeves, I \& Keeble, R. L. 2015.The newspapers handbook.Fifth edition.Abingdondan New York: Routledge.

Robinson, S. \& DeShano, C. 2011. 'Anyone can know': Citizen journalism and the interpretive communityof the mainstream press. Journalism, 12(8), 963-982.

Savolainen, R. 2011. Asking and sharing information in the blogosphere: The case of slimming blogs. Library and Information Science Research, 33, 73-79.

Sumadiria, H. S. 2014. Jurnalistik Indonesia: Menulis beritadan feature. Bandung: Simbiosa Rekatama Media.

Thompson, R. 2010. Writing for broadcast journalists. New York: Routledge.

Walsh, B. 2007.Clear blogging: How people blogging are changing the world and how you can join them. California: Apress.

Wariya, J. D. 2016. A language of play: New media's possibility spaces. Computers and Composition, 40, 32-47. 